\title{
PELAKSANAAN DIVERSI DALAM PERKARA ANAK PADA TINGKAT PEMERIKSAAN PENGADILAN
}

\author{
Waluyadi $[-1$ \\ Program Studi Ilmu Hukum Pascasarjana Universitas Swadaya Gunung Jati
}

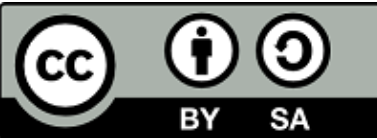

DOI: http://dx.doi.org/10.33603/hermeneutika.v3i2

Diterima: 19 Desember 2019; Direvisi: 27 Januari 2020; Dipublikasikan: Februari 2020

\begin{abstract}
Abstrak: Penyelesaian kasus pidana anak, wajib mengutamakan pendekatan Keadilan Restoratif, yaitu penyelesaian perkara pidana dengan melibatkan pelaku, korban, keluarga pelaku/korban, dan pihak lain yang terkait untuk bersama-sama mencari penyelesaian yang adil dengan menekankan pemulihan kembali pada keadaan semula. Penerapan pendekatan Restoratif Justice dalam perkara anak, diwujudkan dalam bentuk diversi. Permasahan yang muncul adalah bagaimanakah kebijakan prosedural dalam pelaksanaan Diversi dan realitas praktiknya di tingkat pemeriksaan pengadilan. Dalam penelitian ini menggunakan paradigma positivistik. Hukum. Data yang digunakan data sekunder. Pengumpulan data dilakukan dengan studi pustaka. Analisisnya menggunakan analisis kualitatif dengan model interaktif. Kebijakan prosedural dalam pelaksanaan diversi pada tingkat pemeriksaan Pengadilan berpedoman pada UU No. 12 Tahun 2011 dan pada Peraturan Mahkamah Agung No. 4 Tahun 2014. . Dalam praktik di lapangan, terdapat kendala tidak dapat dilakukanya Diversi karena terkendala oleh persyaratan yang kaku sebagaimana tersebut pada pasal 7 ayat (2) hurufa. Undang-Undang No. 12 Tahun 2011.
\end{abstract}

Kata Kunci: Anak, Diversi, Pengadilan

\footnotetext{
1 Waluyadi !

Email: waluyadi01@gmail.com
} 


\section{PENDAHULUAN}

Barda Nawawi Arief dan Muladi menegaskan, ada dua hal yang seharusnya yang mendasari dalam proses peradilan anak, yaitu (1) Anak yang melakukan tindak pidana (kejahatan) bukan dipandang sebagai penjahatan (criminal), tetapi harus dilihat sebagai pihak yang memerlukan bantuan; dan (2) Pendekatan yuridis terhadap anak hendaknya mengutamakan persuasifedukatif dan pendekatan (kejiwaan/psikologis), yakni sejauh mungkin menghindari proses hukum yang semata-mata bersifat menghukum, bersifat degradasi mental dan penurunan semangat (discouragement) serta menghindari proses stigmatisasi yang dapat menghambat proses perkembangan kematangan dan kemandirian yang wajar (Muladi dan Barda Nawawi Arief: 1992:115).

"Anak adalah anak dan bukan orang tua kecil'". Kalimat ini benar adanya, apabila pendekatanya mendasarkan pada fisik. Penerapan kalimat ini dapat menimbulkan masalah, apabila dikaitkan dengan pertanggungjawaban hukum. Kita tidak boleh mengatakan, 'Biarlah dia tidak di pidana, toh masih anak-anak', padahal perilakunya telah menimbulkan korban dan juga kerugian. Kita juga tidak boleh mengatakan, 'Semua perilaku anak yang dikatagorikan sebagai kejahatan, semua harus berahir di Lembaga Pemasyarakatan (LP). Undang-Undang telah menentukan model ''Restorative Justice"' dan model penyelesaian dengan tetap menggunakan "Peradilan Pidana" bagi anak yang berkonflik dengan hukum.

Penyelesaian kasus pidana anak, wajib mengutamakan pendekatan Keadilan Restoratif, yaitu penyelesaian perkara pidana dengan melibatkan pelaku, korban, keluarga pelaku/korban, dan pihak lain yang terkait untuk bersama-sama mencari penyelesaian yang adil dengan menekankan pemulihan kembali pada keadaan semula, dan bukan pembalasan (Pasal 5 ayat (1) Jo. Pasal 1 angka 6 UU Nol. 11 Tahun 2012).

Penerapan pendekatan Restoratif Justice dalam perkara anak, diwujudkan dalam bentuk diversi, yaitu pengalihan penyelesaian perkara anak dari proses peradilan pidana ke proses di luar peradilan pidana. Diversi bertujuan: a. mencapai perdamaian antara korban dan anak; b. menyelesaikan perkara anak di luar proses peradilan; c. menghindarkan anak dari perampasan kemerdekaan; d. mendoromg masyarakat berpatisipasi; dan e. menanamkan rasa tanggung jawab pada anak (Pasal 6 UU No. 11 Tahun 2012).

Pelaksanaan diversi wajib dilakukan pada tingkat penyidikan, penuntutan dan pemeriksaan pengadilan. Diversi hanya dimungkinkan apabila: a. tindak pidana tersebut diancam dengan pidana penjara di bawah 7 (tujuh) tahun; dan b. tindak pidana tersebut bukan pengulangan (Pasal 7 UU No. 11 Tahun 2012).

Mengacu pada Pasal 7 UU No. 11 Tahun 2012, dapat diketahui bahwa dalam perkara anak, tidak semua kasus pidana dapat dimungkinkan diversi. Diversi hanya dimungkinkan bagi tindak pidana yang diancam dengan anacaman pidana di bawah 7 (tujuh) tahun dan bukan residivis. Kemungkinan diversi, tidak berharga mati. Artinya apabila pelaku dan korban tidak menghendaki diversi dan tetap menginginkan menggunakan prosedur hukum pidana, hal itu boleh. Diversi dalam perkara anak hanya pilihan yang di sediakan oleh undang-undang.

Diversi adalah pilihan penyelesaian perkara anak yang diamanatkan oleh Undang-Undang. Sesuai dengan sifatnya, Undang-Undang hanya mengatur hal-hal yang bersifat umum dan prinsip, sementara aturan-aturan yang bersifat praktis harus tersedia. Apabila aturan praktis tersebut tidak ada, maka pelaksanaan diversi akan terhambat bahkan akan gagal.

\section{METODE PENELITIAN}

Dalam penelitian ini menggunakan paradigma positivistik. Hukum dikonsepkan norma-norma dan sebagai putusan hakim, dengan penelitian normatif/doktrinal. Data yang digunakan data sekunder. 
Pengumpulan data dilakukan dengan studi pustaka. Analisisnya menggunakan analisis kualitatif dengan model interaktif.

Obyek penelitian ini adalah putusan hakim tentang perkara tahun 2016 pada Pengadilan Negeri Cirebon dan Pengadilan Negeri Sumber dan juga keputusan/peraturan lembaga penegakan hukum hukum yang bersifat prosedural praktis sebagai landasan pelaksanaan diversi dalam perkara anak di tingkat pemeriksaan pengadilan.

\section{PEMBAHASAN}

\section{Kebijakan prosedural dalam pelaksanaan diversi pada tingkat pemeriksaan Pengadilan.}

\section{a. Dimensi teoretik dan normatif anak}

\section{yang berkonflik dengan hukum}

Jeremy Benthan sebagaimana dikutip oleh Barda Nawawi Arief pernah mengatakan:'Jangan menggunakan hukum pidana tanpa alasan dan dasar yang kuat (groundless), tidak menguntungkan (unprofitable), tidak menunjukan adanya kegunaan/tidak ada gunanya (nedless), dan dalam penggunaanya tidak efektif (inefficaccious)'". Herbert L. Packer juga pernah menyatakan:' 'bahwa penggunaan hukum pidana yang sembarangan (indiscriminactely), secara paksa (coercively), akan menyebabkan sarana hukum pidana itu menjadi suatu ancaman utama (prime ihreatener)' (Barda Nawawi Arief: 2002).

Pendapat Jeremy Benthan dan Herbert L.Packer relevan untuk diadopsi dalam peletakan dasar-dasar pemidanaan bagi anak. Meskipun kesejahteraan harus menjadi tujuan ahir dalam proses penghukuman bagi anak, akan tetapi pada saat situasi menghendaki dan itu tidak ada alternatif lain kecuali menjatuhan pidana bagi anak, maka penjatuhan pidana tersebut harus dianggap sebagai "amputasi".
Artinya, tindakan tersebut memang dilakukan sebagai alternatif yang terahir dan membawa kemanfaatan.

Membiarkan seorang anak memasuki Lembaga Pemasyaratan (LP), berarti memberikan pendidikan negatif kepada anak, sebab di dalam LP penghuninya adalah mereka yang diidentifikasi sebagai yang jahat, maka anak tersebut akan mengimitasi tingkah laku yang jahat. E.H. Sutherlad sebagaimana dikutip oleh TB. Ronny R. Nitibaskoro, pernah mengatakan:' perilaku kriminal dapat dipelajari dalam interaksi dengan orang lain dalam suatu proses komunikasi', (TB Ronny R. Nitibaskoro:2001, : 151-152).

Berangkat dari teori E.H. Suthrland tersebut di atas, kiranya dapat dipahami bahwa terdapat kemungkinan seorang anak yang berada di LP, lambat laun dapat berbekas pada mereka untuk berperilaku jahat. I.S. Susanto (Amarhum) Guru Besar Hukum Pidana UNDIP Semarang, pernah mengatkan: "Hidup adalah soal keakraban dengan kehidupan iu sendiri, apabila seorang anak dipaksa hidup di lingkungan mereka-mereka yang diidentifikasi sebagai yang jahat, maka iapun akan menganggap kejahatan sebagai hal yang biasa'.

Proses diversi dilakukan melalui musyawarah dengan melibatkan anak dan orang tua/walinya, korban dan/atau orang tua/walinya, pembimbing kemasyarakatan, dan pekerja sosial profesional berdasarkan pendekatan restoratif Justis (Pasal 8 ayat (1) UU No.11 Tahun 2012). Dalam pelaksanaan diversi, wajib mempertimbangkan: a, kepentingan korban; b. kesejahteraan dan tanggung jawab anak; c. penghindaran stigma negatif; d. menghindari pembalasan; e. harmonisasi masyarakat;dan f. kepatutan, kesusilaan dan ketertiban umum (Pasal 8 ayat (3) UU No. 11 Tahun 2012).

Kesepakatan diversi harus mendapat persetujuan korban dan/atau keluarga Anak korban serta kesediaan anak dan keluarganya, kecuali untuk: a. tindak pidana yang berupa pelanggaran; b. tindak pidana 
ringan;c. tindak pidana tanpa korban; atau nilai kerugian korban tidak lebih dari nilai upah minimum provinsi setempat (Pasal 9 UU No.11 Tahun 2012).

Hasil kesepakatan diversi dapat berbentuk antara lain: a. perdamaian dengan atau tanpa ganti kerugian; $b$. penyerahan kembali kepada orang tua/wali; c. keikutsertaan dalam pendidikan dan pelatihan di lembaga pendidikan atau LPKS paling lama 3 (tiga) bulan; atau d. pelayanan masyarakat (Pasal 11 UU No. 11 Tahun 2012).

Diversi dalam perkara anak adalah pilihan bagi korban dan pelaku. Apabila pelaku dan korban tidak menginginkanya, maka tetap dapat menggunakan prosedur hukum pidana. Proses peradilan pidana juga dapat dilaksanakan sebagai akibat diversi yang tidak berahir dengan kesepakatan atau sebagai akibat kesepakatan diversi yang di ingkari. Pasal 13 UU No.11 Tahun 2012 menegaskan: 'Proses peradilan pidana bagi anak dilanjutkan dalam hal:a. proses diversi tidak menghasilkan kesepakatan;b. kesepakatan diversi tidak dilaksanakan (Pasal 13 UU No. 11 Tahun 2012).

\section{b. Respon atas pengaturan pidana bagi diversi}

Diversi wajib dilakukan pada tahap pemeriksaan kepolisian/tahap penyidikan, pemeriksaan oleh Jaksa Penuntut Umum/tahap penuntutan, dan tahap pemeriksaan oleh hakim/tahap pemeriksaan pengadilan.

Kewajiban untuk dilakukan diversi pada perkara anak mengacu pada pasalpasal sebagai berikut:

1. Penyidik, Penuntut Umum dan Hakim, yang sengaja tidak melaksanakan kewajiban sebagaimana dimaksud dalam Pasal 7 ayat (1) dipidana dengan pidana penjara paling lama 2 (dua) tahun atau denda paling banyak Rp. 200.000.000,00 (dua ratus juta rupiah) (Pasal 96 UU No.11 Tahun 2012).

2. Hakim yang dengan sengaja tidak melaksanakan kewajiban sebagaimana dimaksud dalam Pasal 35 ayat (3), Pasal 37 ayat (3) dan Pasal 38 ayat (3) dipidana dengan pidana penjara paling lama 2 (dua) tahun (Pasal 100 UU No. 11 Tahun 2012).

3. Pejabat pengadilan yang sengaja tidak melaksanakan kewajiban sebagaimana dimaksud dalam pasal 62 dipidana penjara paling lama 2 (dua) tahun. (Pasal 101 UU No. 11 Tahun 2012).

Berdasarkan pasal 96, 100 dan 101

UU No. 11 Tahun 2012 dapat dipahami:

1. Penyidik, Penuntut Umum dan Hakim wajib mengupayakan diversi dalam perkara anak. Penyidik, Penuntut Umum dan Hakim yang tidak mengupayakan diversi diancam dengan pidana penjara maksimal 2 (dua) tahun atau denda paling banyak Rp. 200.000.000,- (Dua Ratus Juta Rupiah).

2. Hakim yang berkewajiban mengupayakan diversi, bukan hanya hakim Pengadilan Negeri, tetapi mencakup pula Hakim Pengadilan Tinggi dan Hakim Mahkamah Agung. Hakim pada setiap tingkatan yang tidak mengupayakan diversi dalam waktu yang telah ditentukan, diancam dengan pidana penjara paling lama 2 (dua) tahun.

3. Petugas pengadilan yang tidak menyampaikan salinan putusan diversi sampai batas yang ditentukan, diancam dengan pidana penjara paling lama 2 (dua) tahun.

Hakim pada setiap tingkatan, keberatan atas pasal 96, 100 dan 101 Undang-Undang No. 11 Tahun 2012 tentang Sistem Peradilan Pidana Anak, yang di dalamnya mengancam dengan pidana atau denda kepada aparat penegak hukum yang tidak mengupayakan. Keberadaan pasalpasal tersebut dianggap bertentangan dengan kebebasan hakim yang telah dijamin oleh Undang-Undang Dasar Tahun 1945.

Keberatan para hakim atas pasal 96, 100 dan 101 Undang-Undang No. 11 Tahun 2012 diwujudkan dengan mengajukan 
pengujian materiil kepada Mahkamah Konstitusi.

Para permohonan pengujian materiil pasal 96, 100 dan 101 Undang-Undang No. 11 Tahun 2012 tentang Sistem Peradilan Pidana Anak adalah 1. Dr. H. Mohammad Saleh, S.H.,M.H. (Hakim Mahkamah Agung); 2. Dr. Drs. Habiburrahman, M.Hum (Hakim Mahkamah Agung); 3. Dr. Imam Subechi, S.H.,M.H. (Hakim Mahkamah Agung); 4. Imron Anwari, S.H., Sp.N (Hakim Mahkamah Agung); 5. Suhadi, S.H.,M.H. (Hakim Mahkamah Agung); 6. H. Kadar Slamet, S.H.,M.Hum (Hakim Tinggi Pengawas, Mahkamah Agung); 7. I Gusti Agung Sumanantha S.H.,M.H. (Hakim Tinggi, Mahkamah Agung); 8. Drs. Abdul Goni, S.H.,M.H. (Hakim Pengadilan Agama, Mahkamah Agung)' dan 9. Mien Trisnawati,S.H.,M.H. (Wakil Ketua Pengadilan Negeri Metro).

Kesemuanya hakim tersebut adalah anggota Ikatan Hakim Indonesia (IKAHI) yang kepentinganya terganggu, dengan adanya pasal 96, 100 dan 101 UndangUndang No. 11 Tahun 2012 tersebut.

Dalam hal ini berdasarkan Surat Kuasa Khusus tertanggal 22 Oktober 2012 dan Surat Kuasa Khusus Nomor 056/PP.IKAHI/X/2012, tertanggal 22 Oktober 2012 memberi kuasa kepada (1) Dr. Lilik Mulyadi, S.H.,M.H., beralamat di Pengadilan Negeri Jakarta Utara, Jalan Laksamana RE Martadinata No. 4 Jakarta Utara; (2) Tegus Satya Bhakti, S.H,M.H. beralamat di Pengadilan Tata Usaha Negara Semarang, Jalan Abdurahman Saleh No. 89 Semarang; dan (3) Rr. Andy Nurvita, S.H., beralamat di Pengadilan Negeri Salatiga, Jalan Veteran No. 4 Ledok Kota Salatiga, baik bersama-sama maupun sendiri-sendiri bertindak untuk dan atas nama pemberi kuasa.

Berdasarkan permohonan uji materiil ke Mahkamah Konstitui, berdasarkan putusan Nomor: 110/PUU-X/2012, Mahkamah Konstitusi memutuskan bahwa Pasal 96, 100 dan 101 Undang-Undang No.
11 Tahun 2012 bertentangan dengan Undang-Undang Dasar 1945, sehingga tidak memiliki kekuatan hukum mengikat.

Pasal 24 ayat (1) dan ayat (2) Undang-Undang Dasar Tahun 1945 menegaskan (1) Kekuasaan kehakiman merupakan kekuasaan yang merdeka untuk menyelenggarakan peradilan guna menegakkan hukum dan keadilan. (2) Kekuasaan kehakiman dilakukan oleh sebuah Mahkamah Agung dan badan peradilan yang berada di bawahnya dalam lingkungan peradilan umum, lingkungan peradilan agama, lingkungan peradilan militer, lingkungan peradilan tata usaha negara, dan oleh sebuah Mahkamah Konstitusi.

Pelanggaran atas pasal 96, 100 dan 101 adalah pelanggaran hukum formal dan prosedur, sehingga oleh Mahkamah Konstitusi tidak ditafsikan sebagai perbuatan pidana. Kesalahan yudisial (judicial error) tidak sama dengan kesalahan hakim karena melakukan tindak pidana.

Pasal 31 Undang-Undang No. 48 Tahun 2009 tentang Kekuasaan Kehakiman menegaskan hakim pengadilan di bawah Mahkamah Agung merupakan pejabat negara yang melaksanakan kekuasaan kehakiman yang berada pada badan peradilan yang berbeda pada badan peradilan di bawah Mahkamah Agung.

\section{c. Pedoman pelaksanaan diversi.}

Pedoman pelaksanan diversi, diatur dalam Peraturan Mahkamah Agung Republik Indonesia Nomor: 4 Tahun 2014 tanggal 14 Juli 2014 tentang Pedoman Pelaksanaan Diversi dalam Sistem Peradilan Pidana.

Dalam Perma tersebut diatur tentang hal-hal sebagai berikut: 
1. Musyawarah Diversi adalah musyawarah antara para pihak yang melibatkan Anak dan orang tua/Walinya, korban dan/atau orang tua/Walinya, Pembimbing Kemasyarakatan, Pekerja Sosial Profesional, perwakilan masyarakat dan pihak-pihak yang terlibat lainya untuk mencapai kesepakatan Diversi melalui pendekatan Keadilan Restoratif (Pasal 1 ayat (1) Perma No. 4 Tahun 2014).

2. Fasilitator Diversi adalah Hakim yang ditunjuk oleh Ketua Pengadilan untuk menangani perkara anak yang bersangkutan (Pasal 1 ayat (2) Perma No. 4 Tahun 2014).

3. Kaukus adalah pertemuan terpisah antara Fasilitator Diversi dengan salah satu pihak yang diketahui oleh pihak lainya. (Pasal 1 ayat (3) Perma No. 4 Tahun 2014).

4. Kesepakatan diversi adalah kesepakatan hasil proses musyawarah diversi yang dituangkan dalam bentuk dokumen dan ditandatangani oleh para pihak yang terlibat dalam musyawarah Diversi. (Pasal 1 ayat (4) Perma No. 4 Tahun 2014).

5. Diversi diberlakukan terhadap anak yang telah berumur 12 (dua belas) tahun meskipun pernah kawin tetapi belum berumur 18 (delapan belas) tahun, yang diduga melakukan tindak pidana (Pasal 2 Perma No. 4 Tahun 2014).

6. Manurut Pasal 3 Perma No. 4 Tahun 2014), hakim anak wajib mengupayakan Diversi dalam hal Anak didakwa melakukan tindak pidana yang diancam dengan pidana dibawah 7 (tujuh) tahun dan didakwa pula dengan tindak pidana yang diancam dengan pidana penjara 7 (tujuh) tahun atau lebih dalam bentuk surat dakwaan subsideritas, alternatif, kumulatif, maupun kombinasi.

7. Setelah menerima Penetapan Ketua Pengadilan untuk menangani perkara yang wajib diupayakan Diversi Hakim mengeluarkan Penetapan Hari Musyawarah Diversi. Penetapan hakim tersebut memuat perintah kepada penuntut umum yang melimpahkan perkara untuk menghadirkan : a. Anak dan orang tua/Wali atau Pendampingnya; b. Korban dan/atau orang tua/Walinya; c. Pembimbing Kemasyarakatan; d. Pekerja Sosial Profesional; e. Perwakilan masyarakat; dan f. Pihak-pihak terkait lainya yang dipandang perlu untuk dilibatkan dalam musyawarah Diversi. Penetapan hakim tentang hari musyawarah diversi mencantumkan hari, tanggal, waktu serta tempat dilaksananya Musyawarah Diversi (Pasal 4 Perma No. 4 Tahun 2014).

8. Musyawarah Diversi dibuka oleh Fasilitator Diversi dengan dan memperkenalan diri dengan para pihak yang hadir. Fasilitator Diversi menjelaskan maksud dan tujuan diversi, serta tata tertib musyawarah untuk disepakati para pihak yang hadir. Ia juga menjelaskan tentang tugas sebagai Fasilitator Diversi. Fasilitator Diversi menjelaskan ringkasan dakwaan dan Pembimbing Kemasyarakatan memberikan informasi tentang perilaku dan keadaan sosial Anak serta memberikan saran untuk penyelesaian (Pasal 5 ayat (1), (2), dan (3) Perma No. 4 Tahun 2014).

9. Fasilitator Diversi wajib memberikan kesempatan kepada dan untuk: a. Anak untuk didengar keterangan perihal dakwaan; b. Orang tua/Wali untuk menyampaikan hal-hal yang berkaitan dengan perbuatan Anak dan bentuk penyelesaian yang diharapkan; c. Korban/Anak Korban/Orang Tua/Wali untuk memberi tanggapan dan bentuk penyelesaian yang diharapkan (Pasal 5 ayat (4) Perma No. 4 Tahun 2014).

10. Pekerja Sosial Profesional memberikan informasi tentang keadaan sosial Anak Korban serta memberikan saran untuk memperoleh penyelesaian. Apabila dianggap perlu ia dapat memanggil perwakilan masyarakat maupun pihak lain untuk memberikan informasi untuk 
mendukung penyelesaian. Dengan pertimbangan yang sama ia dapat melakukan pertemuan terpisah (kaukus) dengan para pihak (Pasal 5 ayat (5), (6) dan (7) Perma No. 4 Tahun 2014).

11. Fasilitator Diversi menuangkan hasil musyawarah ke dalam Kesepakatan Diversi. Dalam penyusunan kesepakatan diversi, Fasilitator memperhatikan dan mengarahkan agar kesepakatan tidak bertentangan dengan hukum, agama, kepatutan masyarakat setempat, kesusilaan atau memuat halhal yang tidak dapat dilaksanakan Anak; atau memuat itikad tidak baik (Pasal 5 ayat (8) dan (9) Perma No. 4 Tahun 2014).

12. Musyawarah Diversi dicatat dalam Berita Acara Diversi dan ditandatangani oleh Fasilitator Diversi dan Panitera/Penitera Pengganti dan kesepakatan diversi ditandatangani oleh para pihak dan dilaporkan kepada Ketua Pengadilan oleh Fasilitator Diversi. Ketua Pengadilan menerbitkan Penetapan Diversi berdasarkan kesepakatan diversi yang dilaporkan oleh Fasilitator Diversi (Pasal 6 ayat (1), (2) dan (3) Perma No. 4 Tahun 2014).

13. Ketua Pengadilan dapat mengembalikan Kesepakatan Diversi untuk diperbaiki oleh Fasilitator Diversi apabila tidak memenuhi syarat pasal 5 ayat (9) Perma No. 4 tahun 2014, selambat-lambatnya dalam waktu tiga hari. Setelah menerima penetapan dari Ketua Pengadilan menerima Penetapan Kesepakatan Diversi, hakim menerbitkan penetapan penghentian pemeriksaan perkara (Pasal 6 ayat (5) Perma No. 4 Tahun 2014).

14. Dalam hal Kesepakatan Diversi tidak dilaksanakan sepenuhnya oleh para pihak berdasarkan hasil laporan dari Pembimbing Kemasyarakatan Balai Pemasyarakatan, Hakim melanjutkan pemeriksaan perkara sesuai dengan hukum acara peradilan anak. Putusan hakim untuk melanjutkan pemeriksaan perkara tersebut, tetap mempertimbangkan pelaksenaan sebagian Kesepakatan Diversi (Pasal 7 ayat (1) dan (2) Perma No. 4 Tahun 2014).

15. Penetapan Kesepakatan Diversi memuat pula penentuan status barang bukti yang telah disita dengan memperhatikan Kesepakatan Diversi (Pasal 9 Perma No. 4 Tahun 2014).

\section{Realitas pelaksanaan di versi pada}

\section{tingkat pemeriksaan pengadilan}

Berdasarkan studi dokumentasi

terhadap berkas dalam pelaksanaan diversi, dapat diketahui realitas pelaksanaan diversi di tingkat pengadilan negeri sebagai berikut

1. Pelaksanaan diversi pada perkara anak sebagai akibat tidak dilakukanya atau gagalnya diversi pada tingkat penyidikan dan penuntutan;

2. Setelah pengadilan menerima pelimpahan perkara dari Jaksa Penuntut Umum, pengadilan menerbitkan penetapan tentang diversi, yang di dalamnya ditentukan tentang hari dan tanggal, waktu dan tempat dilaksanakanya proses diversi dan memerintahkan kepada Jaksa Penuntut Umum untuk menghadirkan Anak, Orang Tua/Wali/Pendamping, Penasihat Hukum, Anak Korban, Orang Tua/Wali Korban, Pembimbing Kemasyarakatan, Pekerja Sosial Profesional, Tenaga Kesejahteraan Sosial, Perwakilan Masyarakat (RT/RW/Kepala Desa/Tokoh Masyarakat/Agama);

3. Panitera pengganti dan Fasilitator Diversi (Hakim PN) membuat berita acara diversi yang isinya menjelaskan bahwa pihak-pihak yang terkait dengan diversi anak (Anak/Orang 
Tua/Wali/Pendamping/Penasihat

Hukum menyetujui dilakuanya musyawarah);

4. Pelaksanaan diversi, yang di dalamnya dijelaskan tentang ; (1) Keterangan Korban/Orang Tua Korban tentang kronologis kasus/kasus perkara dan akibat dari kasus tersebut, tindakan yang telah dilakukan, misalnya berobat, sikap pelaku atau orang tua pelaku terhadap korban atau keluarga korban dan sikap korban atau orang tua korban terhadap sikap pelaku atau keluarga pelaku. Berita acara pelaksnaan diversi ditanda tangani oleh Panitera Pengganti dan Fasilitator Diversi;

5. Keterangan dalam point 4 diwujudkan dalam kesepakatan Diversi antara korban dan pelaku dan ditandatangi oleh anak dan korban, orang tua atau wali atau pendamping dan disaksikan oleh Pembimbing Kemasyarakatan, Penasihat Hukum, Pekerja Sosial Profesional dan diketahui oleh Fasilitator Diversi;

6. Fasilitator Diversi melaporkan hasil diversi kepada Ketua PN untuk diterbitkan penetapan Diversi berdasarkan Pasal 52 ayat (5) UU No. 11 Tahun 2012.

7. Berdasarkan permohonan dari Fasilitator Diversi, Ketua PN menerbitkan penetapan diversi yang di dalamnya diuraikan tentang: (1) Identitas Anak; (2) Berita Acara Diversi dan Kesepakatan Diversi; (3) Pertimbangan Hakim dalam menerbitkan penetapan Diversi; (4) Penetapan hakim yang isinya a. Mengabulkan permohoan Diversi; $b$. memerintahkan kepada para pihak untuk melaksanakan kesepakatan Diversi; c. memerintahkan kepada penyidik untuk menerbitkan surat perintah penghentian penyidikan/penuntut umum untuk menerbitkan surat perintah penghentian penuntutan /hakim untuk menguatkan penetapan penghentian pemeriksaan setelah kesepakatan Diversi dilaksanakan seluruhnya atau sepenuhnya; d. memerintahkan agar barang bukti dipergunakan dalam perkara lain kepada (yang berhak/korban/terdakwa dalam hal kesepakatan diversi telah dilaksanakan seluruh/sepenuhnya; dan e. memerintahkan panitera menyampaikan salinan penetapan ini kepada Penyidik Anak/Penuntut Umum/Hakim, Pembimbing Kemasyarakatan, Anak/Orang Tua,Korban dan Para Saksi.

8. Ketua PN menetapkan bahwa untuk memelaksanakan penetapan diversi maka perkara yang dimaksud dihentikan.

Menurut Ria Helpina,seorang Hakim Pengadilan Pengadilan Negeri Cirebon yang juga mahasiswa Magiser Hukum Universitas Swadaya Gunung Jati (Unswagati) Cirebon, penerapan diversi oleh hakim terhadap anak yang berhadapan dengan hukum dalam praktik dapat berbeda antara satu dengan yang lainya. ${ }^{2}$

Beberapa perbedaan tersebut, Ria Helpina memberikan contoh sebagai berikut:

\section{Perkara Pidana Nomor: 2/Pid.Sus- Anak/2014/PN Skl. 3}

Terdakwa usia 17 tahun melakukan penganiayaan dengan ancaman pidana dibawah tujuh tahun (Pasal 351 KUHP). Pada tingkat pemeriksaan pengadilan di Pengadilan Negeri Singkil, Hakim anak melakukan Diversi yang tertuang dalam Berita Acara Diversi Nomor: 2/Pid.SusAnak/2014/PN Skl pada tanggal 13 Februari 2015. Antara Anak dan Korban tercapai Kesepakatan Diversi tanggal 15 Februari 2015 yaitu Terdakwa Anak memberikan biaya semangat dan acara adat sebesar Rp. 7.500.000,- (Tujuh Juta

\footnotetext{
${ }^{2}$ Ria Helpina, Problematika Penerapan Diversi Dalam Penegakan Hukum Pidana Anak di Indonesia (Tesis), Magister Hukum, Universitas Swadaya Gunung Jati (Unswagati), Cirebon, 2017 , hlm. 79.

3 Ibid., hlm. 79-80.
} 
Lima Ratus Ribu Rupiah) kepada saksi anak. Kesempatan Diversi tersebut dicantumkan dalam penetapan Nomor: 2/Pid.Sus-Anak/2014/2014/PN Skl.

2. Perkara Pidana Nomor: 05/Pid.SusAnak/2015/PN Bms. ${ }^{4}$

Terdakwa anak usia 16 tahun 9 bulan melakukan penganiayaan terhadap saksi korban anak. Terdakwa melanggar pasal 531 ayat (1) KUHP (ancaman pidana penjara di bawah tujuh tahun). Diversi telah dilakukan, akan tetapi gagal (Diversi Nomor: 05/Pen.Pid.Sus Anak/2015/PN Bms) dan kemudian perkara tetap dilanjutkan.Terdakwa diputus pidana penjara selama 4 bulan.

3. Perkara Pidana Nomor 1/Pid.SusAnak/2016/PN.Skl. ${ }^{5}$

Terdakwa anak berusia 15 tahun melakukan tindak pidana kekerasan atau ancaman kekerasan memaksa anak melakukan persetubuhan denganya atau orang lain terhadap saksi korban anak. Terdakwa melanggar Pasal 81 ayat (1) Undang-Undang Nomor: 35 Tahun 2014 tentang Perubahan atas Undang-Undang No.23 Tahun 2002 tentang Perlindungan Anak (ancaman pidana penjara paling singkat 5 (lima) tahun dan paling lama 15 (lima) tahun dan denda paling banyak Rp. 5.000.000.000,00). Antara Anak dan korban telah dicapai Kesepakatan Diversi tanggal 12 Februari 2016. Kesepakatan diversi tersebut dicantumkan dalam penetapan Diversi Nomor 1/Pid.SusAnak/2016/PN Skl).

4. Perkara Pidana Nomor 16/Pid.SusAnak/2016/PN/Cbn. ${ }^{6}$

Terdakwa Anak usia 16 tahun. Ia didakwa dengan dakwaan Pertama Primer Pasal 340 KUHP (ancaman pidana penjara paling lama 20 Tahun, karena anak maka paling lama 10 Tahun Jo. Pasal 55 ayat (1) ke-1 KUHP, subsider Pasal 338 ayat (1) Jo. Pasal 55 ayat (1) ke-1 KUHP atau Kedua Primer pasal 80 ayat (3) Undang-Undang Nomor 35 Tahun 2014 tentang Perubahan atas Undang-undang No. 23 Tahun 2002 tentang perlindungan anak, subsider Pasal 80 ayat (2) Undang-Undang Nomor 35 Tahun 2014 tentag Perubahan atas Undang-Undang Nomor 23 Tahun 2002 tentang perlindungan anak, lebih subsider Pasal 80 ayat (1) UndangUndang Nomor 35 Tahun 2014 tentang Perubahan atas Undang-Undang Nomor 23 Tahun 2002 tentang Perlindungan Anak (ancaman pidana penjara di bawah tujuh tahun). Diversi telah dilakukan dalam perkara ini berdasarkan Laporan Hakim Anak dan Berita Acara Diversi Nomor 16/Pid.Sus-Anak/2016/PN Cbn namun diversi tidak berhasil dan perkara diulanjtkna ke persidangan. Terdakwa anak diputus dengan pidana penjara penjara selama 10 Tahun (Putusan Nomor 16/Pid.Sus-Anak/2016/PN Cbn).

5. Perkara Pidana Nomor: 14/Pid.SusAnak/2015/PN Rap. ${ }^{7}$

Terdakwa anak usia 17 Tahun melakukan tindak pidana narkotika. Diversi telah dilakukan perkara ini berdasarkan Laporan Hakim Ana dan Berita Acara Diversi Nomor: 14/Pid.SusAnak/2017/PON.Rap tanggal 03 Desember 2015. Divers berhasil mencapai kesepakatan berdasakan penetapan Diversi Nomor 14/Pid.SusAnak/2015/PN.Rap tanggal 03 Desember 2015.

6. Perkara Pidana Nomor 07/Pid.SusAnak/2016/PN.Lgs. ${ }^{8}$

Kasus posisi 3 orang terdakwa anak melakukan tindak pidana narkotika. Diversi tidak dilakukan dalam perkara ini sebagaimana termuat dalam putusan

\footnotetext{
7 Ibid., hlm. 81.
}

8 Ibid., hIm. 82.

5 Ibid., hlm. 80-81.

6 Ibid., hlm. 81. 
Nomor: $\quad$ 07/Pid.Sus-anak/2016/PN.Lgs. dengan alasan antara lain.

a. Perkara para anak adalah benar sebagaimana dimaksud Perma No. 4 Tahun 2014 tentang Pedoman Pelaksanaan Diversi dalam Sistem Peradilan para anak wajib dilakukan Diversi,tetapi haruslah secara kauistis.

b. Bahwa untuk jenis perkara anak yang didakwakan oleh Penuntut Umum masuk dalam Ekstra Ordinary Crime atau perkara Narkoba tentulah mendapat perhatian khusus;

c. Bahwa status anak pada proses pengajian ke Pengadilan sudah dilakukan penahanan

Sebagai gambaran, berikut dikutipkan pelaksanaan pemeriksaan perkara anak pada tingkat pengadilan negeri, di Pengadilan Negeri Cirebon dan Pengadilan Negeri Sumber

a. Penanganan perkara anak tahun 2016 di Pengadilan Negeri (PN) Cirebon

\begin{tabular}{|c|c|c|c|c|}
\hline $\mathrm{N}$ & No. Perkara & $\begin{array}{l}\text { Terda } \\
\text { kwa }\end{array}$ & Perbuatan Pidana & $\begin{array}{c}\text { Putusan } \\
\text { Hakim }\end{array}$ \\
\hline 1. & $\begin{array}{l}\text { 1/Pid.Sus- } \\
\text { Anak/2016/PN. } \\
\text { CBN }\end{array}$ & JA & $\begin{array}{l}\text { Tindak pidana } \\
\text { senjata api atau } \\
\text { benda tajam }\end{array}$ & $\begin{array}{l}\text { Vonis } 2 \\
\text { (dua) } \\
\text { bulan } \\
15 \\
\text { (lima } \\
\text { belas) } \\
\text { hari. }\end{array}$ \\
\hline 2. & $\begin{array}{l}\text { 2/Pid.Sus- } \\
\text { Anak/2016/PN. } \\
\text { CBN }\end{array}$ & TM & $\begin{array}{ll}\text { Tindak } & \text { pidana } \\
\text { pencurian } & \text { dengan } \\
\text { kekerasan } & \end{array}$ & $\begin{array}{l}\text { Vonis } 3 \\
\text { (tiga) } \\
\text { bulan. }\end{array}$ \\
\hline 3. & $\begin{array}{l}\text { 3/Pid.Sus- } \\
\text { Anak/2016/PN. } \\
\text { CBN }\end{array}$ & $\mathrm{TM}$ & $\begin{array}{ll}\text { Tindak } & \text { pidana } \\
\text { pencurian } & \text { dengan } \\
\text { kekerasan } & \end{array}$ & $\begin{array}{l}\text { Divonis } \\
3 \text { (tiga) } \\
\text { bulan. }\end{array}$ \\
\hline 4. & $\begin{array}{l}\text { 4/Pid.Sus- } \\
\text { Anak/2016/PN. } \\
\text { CBN }\end{array}$ & TA & $\begin{array}{l}\text { Tindak pidana } \\
\text { dengan sengaja } \\
\text { membujuk anak } \\
\text { untuk melakukan } \\
\text { persetubuhan }\end{array}$ & $\begin{array}{l}\text { Vonis } \\
10 \\
\text { (sepulu } \\
\text { h) } \\
\text { bulan }\end{array}$ \\
\hline
\end{tabular}

\begin{tabular}{|c|c|c|c|c|}
\hline & & & denganya. & $\begin{array}{l}\text { dan } \\
\text { mengik } \\
\text { uti } \\
\text { latihan } \\
\text { kerja } \\
\text { selama } \\
3 \text { (tiga) } \\
\text { bulan } \\
\text { di } \\
\text { Rumah } \\
\text { Rehabil } \\
\text { itasi } \\
\text { Sosial. }\end{array}$ \\
\hline 5. & $\begin{array}{l}\text { 5/Pid.Sus- } \\
\text { Anak/2016/PN. } \\
\text { CB }\end{array}$ & AA & $\begin{array}{l}\text { Tindak pidana } \\
\text { percobaan } \\
\text { melakukan } \\
\text { pemerasan }\end{array}$ & $\begin{array}{l}\text { Vonis } 3 \\
\text { (tiga) } \\
\text { bulan } \\
15 \\
\text { (lima } \\
\text { belas) } \\
\text { hari }\end{array}$ \\
\hline 6. & $\begin{array}{l}\text { 5/Pid.Sus- } \\
\text { Anak/2016/PN. } \\
\text { CBN }\end{array}$ & TD & $\begin{array}{l}\text { Tindak pidana } \\
\text { dengan sengaja } \\
\text { melakukan } \\
\text { serangaian } \\
\text { kebohongan } \\
\text { membujuk anak } \\
\text { melakukan } \\
\text { persetubuhan } \\
\text { denganya } \\
\text { menerus sebagai } \\
\text { perbuatan } \\
\text { dilanjutkan }\end{array}$ & $\begin{array}{l}\text { Dipenja } \\
\text { ra } \\
\text { tahun } \\
\text { dan } \\
\text { pidana } \\
\text { Pelatiha } \\
\text { n Kerja } \\
\text { di } \\
\text { LPKS } \\
\text { Balai } \\
\text { Rehabil } \\
\text { itasi } \\
\text { Sosial } \\
\text { Marsud } \\
\text { i Putra } \\
\text { (BRSM } \\
\text { ) } \\
\text { Cilengs } \\
\text { i Bogor } \\
\text { selama } \\
\text { 1 tahun }\end{array}$ \\
\hline 7. & $\begin{array}{l}\text { 7/Pid.Sus/2016/ } \\
\text { PN.CBN }\end{array}$ & MR & $\begin{array}{lr}\text { Tindak } & \text { pidana } \\
\text { tanpa } & \text { hak } \\
\text { menguasai,memba } \\
\text { wa,sesuatu } & \text { senjata } \\
\text { pemukul, senjata } \\
\text { penikaman } \quad \text { atau } \\
\text { senjata penusukan }\end{array}$ & $\begin{array}{l}\text { Vonis } 4 \\
\text { bulan } \\
\text { penjara }\end{array}$ \\
\hline 8. & $\begin{array}{l}\text { 8/Pid.Sus- } \\
\text { Anak/2016/PN. }\end{array}$ & IA & $\begin{array}{lr}\text { Tindak } & \text { Pidana } \\
\text { dengan } & \text { sengaja }\end{array}$ & $\begin{array}{l}\text { Vonis } 1 \\
\text { tahun } 6\end{array}$ \\
\hline
\end{tabular}




\begin{tabular}{|c|c|c|c|c|}
\hline & $\mathrm{CBN}$ & & $\begin{array}{l}\text { membujuk anak } \\
\text { untuk melakukan } \\
\text { persetubuhan } \\
\text { denganya }\end{array}$ & $\begin{array}{l}\text { bulan } \\
\text { dan } \\
\text { mengiu } \\
\text { ti wajib } \\
\text { kerja } \\
\text { selama } \\
2 \text { bulan } \\
\text { di Balai } \\
\text { Rehabil } \\
\text { itasi } \\
\text { Sosial } \\
\text { Marsud } \\
\text { i Putra } \\
\text { (BRSM } \\
\text { P) } \\
\text { Cilengs } \\
\text { i Bogor } \\
\text { Jawa } \\
\text { Barat }\end{array}$ \\
\hline 9. & $\begin{array}{l}\text { 9/Pid.Sus- } \\
\text { Anak/2016/PN. } \\
\text { CBN }\end{array}$ & DJ & $\begin{array}{ll}\text { Tindak } & \text { Pidana } \\
\text { pencurian } & \text { dengan } \\
\text { kekerasan } & \end{array}$ & $\begin{array}{l}\text { Vonis } 3 \\
\text { bulan } \\
\text { penjara }\end{array}$ \\
\hline 0 . & $\begin{array}{l}\text { 10/Pid.Sus- } \\
\text { Anak/2016/PN. } \\
\text { CBN }\end{array}$ & MR & $\begin{array}{l}\text { Tindak Pidana } \\
\text { pencurian dengan } \\
\text { kekerasan dalam } \\
\text { keadaan } \\
\text { memberatkan }\end{array}$ & $\begin{array}{l}\text { Vonis } 4 \\
\text { bulan } \\
\text { di } \\
\text { LPKA } \\
\text { Bandun } \\
\mathrm{g}\end{array}$ \\
\hline 1. & $\begin{array}{l}\text { 11/Pid.Sus- } \\
\text { Anak/2016/PN. } \\
\text { CBN }\end{array}$ & $\mathrm{AR}$ & \begin{tabular}{lr} 
Tindak & Pidana \\
tanpa & hak \\
membawa & senjata \\
pemukul, & senjata \\
penikam & atau \\
\multicolumn{2}{l}{ senjata penusuk }
\end{tabular} & $\begin{array}{l}\text { Vonis } 3 \\
\text { bulan } \\
\text { penjara }\end{array}$ \\
\hline 2. & $\begin{array}{l}\text { 12/Pid.Sus- } \\
\text { Anak/2016/PN- } \\
\text { CBN }\end{array}$ & NA & $\begin{array}{lr}\text { Tindak } & \text { Pidana } \\
\text { tanpa } & \text { hak } \\
\text { membawa } & \text { sesuatu } \\
\text { senjata } & \text { penikaman } \\
\text { atau } & \text { senjata } \\
\text { penusuk } & \end{array}$ & $\begin{array}{l}\text { Vonis } 4 \\
\text { bulan } \\
\text { penjara }\end{array}$ \\
\hline 3. & $\begin{array}{l}\text { 13/Pid.Sus- } \\
\text { Anak/2016/PN. } \\
\text { CBN }\end{array}$ & FA & $\begin{array}{l}\text { Tindak pidana } \\
\text { secara bersama- } \\
\text { sama melakukan } \\
\text { pencurian dengan } \\
\text { kekerasan }\end{array}$ & $\begin{array}{l}\text { Vonis } \\
\text { penjara } \\
6 \text { bulan }\end{array}$ \\
\hline 1 & $\begin{array}{l}\text { 14/Pid.Sus- } \\
\text { Anak/2016/PN. }\end{array}$ & MA & $\begin{array}{l}\text { Diversi dinyatakan } \\
\text { berhasil dan proses }\end{array}$ & \\
\hline
\end{tabular}

\begin{tabular}{|c|c|c|c|c|}
\hline & $\mathrm{CBN}$ & & $\begin{array}{l}\text { perkara tidak } \\
\text { dilanjutkn. } \\
\text { Terdakwa dijerat } \\
\text { dengan Pasal } 170 \\
\text { ayat (1) KUHP }\end{array}$ & \\
\hline $\begin{array}{l}1 \\
5 .\end{array}$ & $\begin{array}{l}\text { 15/Pid.Sus- } \\
\text { Anak/2016/PN. } \\
\text { CBN }\end{array}$ & EP & $\begin{array}{lr}\text { Tindak } & \text { Pidana } \\
\text { pencurian } & \text { dengan } \\
\text { kekerasan } & \text { dalam } \\
\text { keadaan } & \\
\text { memberatkan }\end{array}$ & $\begin{array}{l}\text { Vonis } 1 \\
\text { bulan } \\
\text { penjara }\end{array}$ \\
\hline $\begin{array}{l}1 \\
6 .\end{array}$ & $\begin{array}{l}\text { 16/Pid.Sus- } \\
\text { Anak/2016/PN. } \\
\text { CBN }\end{array}$ & ST & $\begin{array}{l}\text { Tindak Pidana } \\
\text { bersama-sama } \\
\text { merencanakan } \\
\text { pembunuhan } \\
\text { berencana }\end{array}$ & $\begin{array}{l}\text { Vonis } 8 \\
\text { Tahun } \\
\text { (Divers } \\
\text { i tidak } \\
\text { berhasil } \\
\text { ). }\end{array}$ \\
\hline
\end{tabular}

Penanganan perkara anak tahun 2016 di

\section{Pengadilan Negeri (PN) Sumber}

\begin{tabular}{|c|c|c|c|c|}
\hline No & No. Perkara & $\begin{array}{c}\text { Terdakw } \\
\text { a }\end{array}$ & Perbuatan Pidana & $\begin{array}{c}\text { Putusan } \\
\text { Hakim }\end{array}$ \\
\hline 1. & $\begin{array}{l}\text { No1/Pid.Sus- } \\
\text { Anak/2016/PN.Sbr. }\end{array}$ & MA & $\begin{array}{l}\text { Tindak pidana } \\
\text { membawa } \\
\text { senjata tajam } \\
\text { tanpa hak }\end{array}$ & $\begin{array}{l}\text { Vonis } \\
\text { (7) } \\
\text { tujuh } \\
\text { bulan }\end{array}$ \\
\hline 2. & $\begin{array}{l}\text { No.2/Pid.Sus- } \\
\text { Anak/2016/PN.Sbr. }\end{array}$ & $\mathrm{AM}$ & $\begin{array}{l}\text { Tindak pidana } \\
\text { membawa } \\
\text { senjata tajam } \\
\text { tanpa hak }\end{array}$ & $\begin{array}{l}\text { Vonis } \\
\text { (3) tiga } \\
\text { bulan }\end{array}$ \\
\hline 3. & $\begin{array}{l}\text { No.3/Pid.Sus- } \\
\text { Anak/2016/PN.Sbr. }\end{array}$ & $\mathrm{RB}$ & $\begin{array}{l}\text { Tindak pidana } \\
\text { membawa } \\
\text { senjata tajam } \\
\text { tanpa hak }\end{array}$ & $\begin{array}{l}\text { Vonis } \\
\text { (2) dua } \\
\text { bulan }\end{array}$ \\
\hline 4. & $\begin{array}{l}\text { No.4/Pid.Sus- } \\
\text { Anak/2016/PN.Sbr. }\end{array}$ & $\mathrm{AG}$ & $\begin{array}{l}\text { Tindak pidana } \\
\text { pencurian } \\
\text { dengan } \\
\text { pemberatan }\end{array}$ & $\begin{array}{l}\text { Vonis } \\
\text { (3) tiga } \\
\text { bulan }\end{array}$ \\
\hline 5. & $\begin{array}{l}\text { No.5/Pid.Sus- } \\
\text { Anak/2016/PN.Sbr. }\end{array}$ & JD & $\begin{array}{l}\text { Persetubuhan } \\
\text { dengan anak } \\
\text { secara } \\
\text { kekerasan } \\
\text { sehingga } \\
\text { meninggal } \\
\text { dunia }\end{array}$ & $\begin{array}{l}\text { Vonis } \\
\text { (10) } \\
\text { Sepulu } \\
\text { h } \\
\text { Tahun } \\
\text { (3) tiga } \\
\text { bulan }\end{array}$ \\
\hline 6. & $\begin{array}{l}\text { No. 6/Pid.Sus- } \\
\text { Anak/2016/PN.Sbr. }\end{array}$ & PK & $\begin{array}{l}\text { Tindak pidana } \\
\text { cabul }\end{array}$ & $\begin{array}{l}\text { Vonis } \\
\text { (7) }\end{array}$ \\
\hline
\end{tabular}




\begin{tabular}{|c|c|c|c|c|}
\hline & & & & $\begin{array}{l}\text { Tujuh } \\
\text { tahun } \\
(6) \\
\text { Enam } \\
\text { bulan }\end{array}$ \\
\hline 7. & $\begin{array}{l}\text { No.7/Pid.Sus- } \\
\text { Anak/2016/PN.Sbr. }\end{array}$ & AN & $\begin{array}{l}\text { Tindak pidana } \\
\text { cabul }\end{array}$ & $\begin{array}{l}\text { Vonis } \\
\text { (2) dua } \\
\text { tahun } \\
\text { (3) tiga } \\
\text { bulan }\end{array}$ \\
\hline 8. & $\begin{array}{l}\text { No.8/Pid.Sus- } \\
\text { Anak/2016/PN.Sbr. }\end{array}$ & $\mathrm{ME}$ & $\begin{array}{l}\text { Tindak pidana } \\
\text { cabul }\end{array}$ & $\begin{array}{l}\text { Vonis } \\
\text { (4) } \\
\text { Empat } \\
\text { tahun } 6 \\
\text { (enam) } \\
\text { bulan }\end{array}$ \\
\hline 9. & $\begin{array}{l}\text { No. 9/Pid.Sus- } \\
\text { Anak/2016/PN. Sbr. }\end{array}$ & GG & $\begin{array}{l}\text { Tindak pidana } \\
\text { senjata tajam }\end{array}$ & $\begin{array}{l}\text { Vonis } \\
\text { (4) } \\
\text { empat } \\
\text { bulan }\end{array}$ \\
\hline 10 & $\begin{array}{l}\text { No.10/Pid.Sus- } \\
\text { Anak/2016/PN.Sbr. }\end{array}$ & SN & $\begin{array}{l}\text { Tindak pidana } \\
\text { menghilangkan } \\
\text { jiwa anak } \\
\text { sendiri }\end{array}$ & $\begin{array}{l}\text { Vonis } \\
\text { (1) } \\
\text { tahun } \\
(10) \\
\text { sepuluh } \\
\text { bulan }\end{array}$ \\
\hline 11 & $\begin{array}{l}\text { No. 11/Pid.Sus- } \\
\text { Anak/2016/PN.Sbr. }\end{array}$ & IG & $\begin{array}{l}\text { Tindak pidana } \\
\text { membawa } \\
\text { senjata tajam }\end{array}$ & $\begin{array}{l}\text { Vonis } 3 \\
\text { (tiga) } \\
\text { bulan }\end{array}$ \\
\hline 12 & $\begin{array}{l}\text { No.12/Pid.Sus- } \\
\text { Anak/2016/PN.Sbr. }\end{array}$ & MM & $\begin{array}{l}\text { Tindak pidana } \\
\text { penipuan dana } \\
\text { atau } \\
\text { penggelapan }\end{array}$ & $\begin{array}{l}\text { Vonis } 4 \\
\text { (empat) } \\
\text { bulan }\end{array}$ \\
\hline 13 & $\begin{array}{l}\text { No.13/Pid.Sus- } \\
\text { Anak/2016/PN.Sbr. }\end{array}$ & MJ & $\begin{array}{l}\text { Tindak Pidana } \\
\text { cabul }\end{array}$ & $\begin{array}{l}\text { Vonis } 2 \\
\text { (dua) } \\
\text { Tahun }\end{array}$ \\
\hline 14 & $\begin{array}{l}\text { No.14/Pid.Sus- } \\
\text { Anak/2016/PN.Sbr. }\end{array}$ & SB & $\begin{array}{l}\text { Tindak pidana } \\
\text { membawa } \\
\text { senjata tajam } \\
\text { tanpa ijin }\end{array}$ & $\begin{array}{l}\text { Vonis } \\
\text { (3) tiga } \\
\text { bulan }\end{array}$ \\
\hline 15 & $\begin{array}{l}\text { No. 15/Pid.Sus- } \\
\text { Anak/2016/PN.Sbr. }\end{array}$ & $\mathrm{MF}$ & $\begin{array}{l}\text { Tindak pidana } \\
\text { pidana } \\
\text { pencurian } \\
\text { dengan } \\
\text { kekerasan }\end{array}$ & $\begin{array}{l}\text { Vonis } \\
\text { (7) } \\
\text { Tujuh } \\
\text { bulan }\end{array}$ \\
\hline 16 & $\begin{array}{l}\text { No. 16/Pid.Sus- } \\
\text { Anak/2016/PN.Sbr. }\end{array}$ & FP & $\begin{array}{l}\text { Tindak pidana } \\
\text { pembunuhan }\end{array}$ & $\begin{array}{l}\text { Vonis } \\
(5) \\
\text { bulan }\end{array}$ \\
\hline 17 & $\begin{array}{l}\text { No.17/Pid.Sus- } \\
\text { Anak/2016/PN.Sbr. }\end{array}$ & IB & Tindak pidana & Vonis \\
\hline
\end{tabular}

\begin{tabular}{|c|c|c|c|c|}
\hline . & & & $\begin{array}{l}\text { pencurian } \\
\text { dengan } \\
\text { pemberatan }\end{array}$ & $\begin{array}{l}\text { (5) lima } \\
\text { bulan }\end{array}$ \\
\hline 18 & $\begin{array}{l}\text { No.18/Pid.Sus- } \\
\text { Anak/2016/PN.Sbr. }\end{array}$ & PB & $\begin{array}{l}\text { Tindak pidana } \\
\text { cabul }\end{array}$ & $\begin{array}{l}\text { Vonis } 1 \\
\text { (satu) } \\
\text { Tahun } \\
6 \\
\text { (enam) } \\
\text { bulan }\end{array}$ \\
\hline 19 & $\begin{array}{l}\text { No. 19/Pid.Sus- } \\
\text { Anak/2016/PN.Sbr. }\end{array}$ & $\mathrm{ME}$ & $\begin{array}{l}\text { Tindak pidana } \\
\text { pencurian } \\
\text { dengan } \\
\text { pemberatan }\end{array}$ & $\begin{array}{l}\text { Vonis } 5 \\
\text { (lima) } \\
\text { bulan }\end{array}$ \\
\hline 20 & $\begin{array}{l}\text { No.20/Pid.Sus- } \\
\text { Anak/2016/PON.Sbr }\end{array}$ & IY & $\begin{array}{l}\text { Tindak pidana } \\
\text { pencurian } \\
\text { dengan } \\
\text { kekerasan }\end{array}$ & $\begin{array}{l}\text { Vonis } 2 \\
\text { (dua) } \\
\text { bulan }\end{array}$ \\
\hline 21 & $\begin{array}{l}\text { No. 21/Pid.Sus- } \\
\text { Anak/2016/PN.Sbr. }\end{array}$ & AS & $\begin{array}{l}\text { Tindak pidana } \\
\text { pencurian } \\
\text { dengan } \\
\text { pemberatan }\end{array}$ & $\begin{array}{l}\text { Vonis } 6 \\
\text { (enam) } \\
\text { bulan }\end{array}$ \\
\hline 22 & $\begin{array}{l}\text { No.22/Pid.Sus- } \\
\text { Anak/2016/PN.Sbr. }\end{array}$ & $\mathrm{NN}$ & $\begin{array}{l}\text { Tindak pidana } \\
\text { membawa } \\
\text { senjata tajam } \\
\text { tana ijin }\end{array}$ & $\begin{array}{l}\text { Vonis } 3 \\
\text { (tiga) } \\
\text { bulan }\end{array}$ \\
\hline 23 & $\begin{array}{l}\text { No. 23/Pid.Sus- } \\
\text { Anak/2016/PN.Sbr. }\end{array}$ & RA & $\begin{array}{l}\text { Tindak pidana } \\
\text { cabul }\end{array}$ & $\begin{array}{l}\text { Vonis } 2 \\
\text { (dua) } \\
\text { tahun } \\
1 \text { (satu) } \\
\text { bulan }\end{array}$ \\
\hline 24 & $\begin{array}{l}\text { No. 24/Pid.Sus- } \\
\text { Anak/2016/PN.Sbr. }\end{array}$ & SA & $\begin{array}{l}\text { Tindak pidana } \\
\text { mengedarkan } \\
\text { sediaan tanpa } \\
\text { ijin }\end{array}$ & $\begin{array}{l}\text { Vonis } 6 \\
\text { (enam) } \\
\text { bulan }\end{array}$ \\
\hline 25 & $\begin{array}{l}\text { No.25/Pid.Sus- } \\
\text { Anak/2016/PN.Sbr. }\end{array}$ & SB & $\begin{array}{l}\text { Tindak pidana } \\
\text { cabul }\end{array}$ & $\begin{array}{l}\text { Vonis } 3 \\
\text { (tiga) } \\
\text { bulan }\end{array}$ \\
\hline 26 & $\begin{array}{l}\text { No.26/Pid.Sus- } \\
\text { Anak/2016/PN.Sbr. }\end{array}$ & FA & $\begin{array}{l}\text { Tindak pidana } \\
\text { sajam }\end{array}$ & $\begin{array}{l}\text { Vonis } 2 \\
\text { (dua) } \\
\text { bulan }\end{array}$ \\
\hline 27 & $\begin{array}{l}\text { No.27/Pid.Sus- } \\
\text { Anak/2016/PN.Sbr. }\end{array}$ & $\mathrm{MH}$ & $\begin{array}{l}\text { Tindak pidana } \\
\text { penyalahgunaa } \\
\text { n narkotika }\end{array}$ & $\begin{array}{l}\text { Vonis } 2 \\
\text { (dua) } \\
\text { tahun }\end{array}$ \\
\hline
\end{tabular}

Dari catatan pihak Pengadilan Negeri Cirebon, perkara anak yang tercantum pada angka 16 (enam belas) diversi tidak berhasil, karena pihak keluarga korban tidak bersedia dilakukan diversi. Dari 16 perkara anak yang masuk ke PN 
Cirebon, 1 berhasil di diversi dan 1 tidak berhasil didiversi, selebihnya tidak dilakukan diversi karena tidak memenuhi Pasal 7 ayat (2) Undang-Undang Sistem Peradilan Pidana Anak.

Pasal 7 Undang-Undang No. 12 Tahun 2011 menegaskan; (1) Pada tingkat penyidikan, penuntutan, dan pemeriksaan perkara Anak di pengadilan negeri wajib diupayaan Diversi. (2) Diversi sebagaimana dimaksud pada ayat (1) dilaksanakan dalam hal tindak pidana yang dilakukan: a. diancam dengan pidana di bawah 7 (tujuh) tahun; dan b. bukan merupakan pengulangan tindak pidana.

Pada awalnya keberadaan Pasal 7

ayat (1) Undang-Undang No. 12 Tahun 2011 mengikat dan memaksa penegak hukum (penyidik, jaksa, dan hakim) untuk mengupayakan Diversi, apabila memenuhi syarat sebagaimana disebutkan pada pasal 7 ayat (2) UU No. 12 Tahun 2011. Pelanggaran terhadap pasal tersebut akan dikenai hukuman sebagaimana diatur dalam Pasal 96, 100 dan 101.

Ketiga pasal tersebut $(96,100$ dan 101 UU No. 12 Tahun 2011) berdasarkan putusan Mahkamah Konstitusi Nomor: 110/PUU-X/2012 tidak memiliki kekuatan hukum mengikat, karena bertentangan dengan Undang-Undang Dasa Tahun 1945.

Menurut hemat penulis pasca putusan Mahkamah Agung tersebut, aparat penegak hukum (dalam hal ini hakim) secara moral tetap berkawiban untuk mengupayakan diversi apabila perkara anak tersebut memenuhi syarat untuk diupayakan Diversi. Demikian juga, dengan pertimbangan moral hakim tidak seharusnya menolak permohonan Diversi apabila syarat untuk itu terpenuhi.

Di Pengadilan Negeri Cirebon dari 16 perkara anak dalam waktu 1 (satu) 14 (empat belas) dinyatakan tidak upayakan Diversi, karena tidak memenuhi syarat. Sebagaimana diatur dalam Pasal 7 ayat (2) Undang-Undang No. 12 Tahun 2011, Diversi hanya dimungkinkan terhadap kasus pidana yang diancam pidana di bawah 7 (tujuh) tahun dan bukan residivis. Pasal ini seolah-olah menghendaki, seorang anak untuk mengetahui terlebih dahulu bahwa perbuatan yang dilakukan diancam dengan pidana dibawah 7 (tujuh) tahun, sehingga dapat dilakukan. Tuntutan yang demikian, menjadi sangat tidak mungkin.

Sebelum lahirnya UU No. 3 Tahun 1997 tentang Pengadilan Anak dan UU No.12 Tahun 2011 tentang Sistem Peradilan Pidana Anak, Mahkamah Agung telah member perhatian terhadap perkara yang terdakwanya adalah anak. Perhatian yang cukup esensial menurut hemat penulis adalah terbitkanya SEMA No.1 Tahun 1959 tentang Pemanfatan Yayasan Pra Yuwana Indonesia dalam memberikan konsultasi dan bantuan hukum bagi anak Indonesia.

Dalam SEMA tersebut disebutkan antara lain, pendekatan filosofis terhadap pelanggar hukum usia anak Indonesia disebabkan dua faktor,yaitu: ${ }^{9}$

a. Anak belum mengerti benar akan kesalahan yang diperbuat, sehingga sudah sepantasnya diberikan/diberlakukan pengurangan hukuman serta pembedaan pemberian hukuman bagi anak dengan orang dewasa.

b. Dibina disadarkan akan kesalahanya yang sepatutnya tidak ia lakukan.

Apabila oleh Mahkamah Agung, anak dianggap belum mengerti benar akan kesalahan yang diperbuat, mengapa Undang-Undang memberikan persyaratan dalam pengupayaan Diversi?, yaitu hanya untuk tindak pidana yang diancam dengan pidana dibawah 7 (tujuh) tahun. Pertimbangan lainya adalah, tidak ada yang tahu jenis perbuatan yang akan dilakukan, yang diketahui oleh orang dewasa adalah bahwa anak telah melakukan perbuatan

\footnotetext{
${ }^{9}$ Marlina, Peradilan Pidana Anak di Indonesia (Pengembangan Konsep Restoratuve Justice), Reflika Aditama, Cetakan Pertama, Bandung, November, 2009, hlm. 132.
} 
yang oleh Undang-Undang diancam dengan pidana. Apabila Diversi tertutup oleh persyaratan yang begitu ketat, maka tujuan perlindungan anak yang berhadapan dengan hukum, semakin jauh.

Dari 16 kasus perkara anak yang ditangani di Pengadilan Negeri Cirebon, 14 (empat belas) kasus dijatuhi pidana paling lama 1 (satu) tahun dan di dibawah 1 (satu) tahun serta satu kasus dipidana 8 (delapan) tahun penjara. Untuk kasus di Pengadilan Negeri Sumber, dari 27 kasus perkara anak tidak dilakukan Diversi karena tidak memenuni syarat dan dijatuhi pidan antara 2 (dua) buan sampai 10 (sepuluh) tahun.

Pada saat peresmian ruang sidang anak di Pengadilan Negeri Bandung tanggal 13 Agustus 2004, Bagir Manan yang pada saat itu menjadi Ketua Mahkamah Agung menyatakan: ${ }^{10}$ "Saya tidak ingin menggunaka kata-kata perbuatan jahat bagi anak yang berkonflik dengan hukum, tetapi menggunakan kata perbuatan nakal luar buasa, seorang anak tidak boleh dijatuhi hukuman maksimum, karena pada dasarnya secara pikiran-pikian konseptual berangkat dari pola pikir tidak ada anak jahat,tetapi anak sebagai korban.

Pertanyaan yang cukup urgen berkaitan dengan penyelesaian kasus anak adalah kapan seorang anak dianggap memahami atas kesalahan dari perbuatanya? Dalam menjatuhkan pidana terhadap anak haruslah sangat berhati-hati, jika tidak ada pilihan lain seperti si anak sudah berkali-kali melakukan perbuatan pidana dan sifat kejahatanya meningkat. Peradilan pidana anak perlu memfokuskan titik perhatianya pada dua hal, yaitu masa depan pelanggaran hukum yang berusia muda atau belum dewasa dan akibat sosiologis dan psikologis akibat diterapkanya suatu jenis hukuman. ${ }^{11}$ Apapun alasanya, Pengadilan tidak harus disalahkan. Pengadilan hanya institusi yang melaksanakan Undang-Undang. Peradilan adalah tiang teras dan landasan negara

10 Ibid.,hlm. 176.

11 Wagiati Soetojo, Hukum Pidana Anak, Refika Aditama Cetakan ketiga, Bandung, 2010, hlm. 74 hukum. Peraturan hukum yang diciptakan memberikan faedah apabila ada peradilan yang berdiri kokoh/kuat dan bebas cari pengaruh apapun, yang dapat memberiian isi dabn kekuatan kepada kaidah-kaidah hukum yang diletakan dalam undangundang dan pertanyaan lainya. Peradilan juga merupakan instansi yang merupakan tempat setiap orang mencari keadilan dan menyelesaikan persoalan tentang hak dan kewajibanya menurut hukum. ${ }^{12}$

Perubahan akan dan dapat dimulai dari pembentuk Undang-Undang. Apakah anak akan menjadi subyek Undang-Undang atau hanya menjadi obyek. Apabila anak karena alasan Undang-Undang belum dan tidak dapat menikmati Dibersi, maka keberadaan Undang-Undang No. 12 Tahun 2011 bagi anak tetap menjadi obyek dan bukan subyek dan ini berarti terjadi ketidaksinkronan antara dasar pertimbangan ditetapkanya Undang-Undang tersebut dengan pasalpasal yang terdapat di dalamnya.

Penjelasan umum Undang-Undang No. 12 Tahun 2011 menegaskan:"Adapun substansi yang diatur dalam UndangUndang ini, antara lain, mengenal penempatan anak yang menjalani proses peradilan dapat ditempatkan di Lembaga Pembinaan Khusus Anak (LPKA). Substansi yang paling mendasar dalam Undang-Undang ini adalah pengaturan

Pada hakekatnya, batasan anak dalam kaitanya dengan hukum pidana yang berarti melingkupi anak nakal, meliputi dimensi $:^{13}$

1. ketidakmampuan untuk pertanggungngjawaban tindak pidana;

2. pengembalian hak-hak anak dengan jalan mensubtitusikan hak-hak anak yang timbul dari lapangan hukum keperdataan, tata negara dengan maksud untuk mensejahterakan anak;

\footnotetext{
12 Sri Widoyati Wiratmo Soekito dalam Maidin Gultom, Perlindungan Hukum terhadap Anak dalam Ssistem Pidana Anak di Indonesia Cetakan kedua, Refika Aditama, Bandung, 2010,hlm. 64

13 Maulana Hasan Wadong dalam Nashriana, Perlindungan Hukum Pidana bagi Anak di Indonesia, Cetakan Ke-3, PT. RadjaGrafindo Persada, Jakarta,2014, hlm. 8.
} 
3. rehabilitasi, yaitu anak berhak mendapatkan perbaikan mental sepiritual akibat dari tindakan hukum pidana yang dilakukan anak itu sendiri;

4. hak-hak untuk menerima pelayanan dan asuhan;

5. hak-hak anak dalam proses hukum acara pidana.

Upaya perlindungan anak perlu dilaksanakan seusia muda mungkin, yakni sejak dari janin dalam kandungan sampai anak berumur 18 (Delapan Belas) tahun. Bertitik tolak dari konsepsi perlindungan anak yang utuh, menyeluruh dan konprehenshif, pembangunan sumber daya manusia ini meletakan kewajiban memberikan perlindungan kepada anak berdasarkan asas-asas: 1. Nondiskriminasi; 2. Kepentingan yang terbaik bagi anak; 3 . Hak untuk hidup, kelangsungan hidup dan perkembangan ; dan 4. Perkembangan terhadap pendapat anak. ${ }^{14}$ adalah: ${ }^{15}$

Prinsip-prinsip Perlindungan Anak

a. Anak tidak dapat berjuang sendiri; Anak itu modal utama kelangsungan hidup manusia, bangsa dan keluarga, untuk itu hak-haknya harus dilindungi. Anak tidak dapat melindungi sendiri hakhaknya, banyak pihak yang mempengaruhi kehidupanya. Negara dan masyarakat kepentingan untuk mengusahakan perindungan hak-hak anak.

b. Kepentingan terbaik anak (the best interest of the child); Agar perlindungan anak dapat diselenggarakan dengan baik, dianut prinsip yang menyatakan bahwa kepentingan terbaik anak harus

14 Budiman Al Hanif dalam H.M. Abdi Koro, Perlindungan Anak di Bawah Umum dalam Perkawinan UsiaMuda dan Perkawinan Siri, Cetakan Kesatu, PT.Alumni, Bandung, 2012, hlm. 6.

15 Maidan Gultom, Perlindungan Hukum terhadap Anak dan Perempuan, Cetakan Ketiga, Refika Aditama, Bandung, 2014, hlm. 71-72 dipandang sebagai of paramount importence (memperoleh prioritas tertinggi) dalam setiap keputusan yang menyangkut anak.

c. Ancangan daur kehidupan (life-circle approach); Perlindungan anak mengacu pada pemahaman bahwa perlindungan anak harus dimulai sejak dini dan terus menerus.

d. Lintas sektoral: Nasib anak tergantung dari berbagai faktor, baik yang makro maupun yang mikro, yang langsung maupun yang tidak langsung.

Undang-Undang No. 12 Tahun 2011 masih memberikan ruang bagi hakim untu menjatuhkan pidana penjara bagi anak. Penjatuhan penjara tersebut, tentunya secara normatif telah melalui tahapan yang cukup panjang. Persoalan yang muncul adalah ketersediaan Lembaga Pemasyarakatan (LP) anak yang untuk seluruh anak Indonesia yang telah ditetapkan menjadi narapidana. Sudahkan pada setiap kota/kabupaten tersedia LP anak? Sebagai contoh kapasitas Lapas Anak Tanggerang yang hanya dipersiapkan untuk 220 anak terpaksa menampung 343 anak laki-laki dengan rentang usia jauh antara 12 hingga 26 tahun. Akibatnya, sel berukuran 1x1,5 meter yang seharusnya hanya untuk 1 anak,terpaksa dihuni 3 anak. ${ }^{16}$

\section{KESIMPULAN}

\begin{tabular}{lrr}
\multicolumn{1}{c}{ Kebijakan } & prosedural & dalam \\
pelaksanaan diversi pada & tingkat \\
pemeriksaan & Pengadilan. & Dasar \\
penjatuhan bagi anak harus bermuara & ban \\
pada kesejahteraan anak dan harus \\
merupakan altetnatif terahir. Membiarkan \\
anak berada dalam rembaga
\end{tabular}

16 www.kompas.com/kompascetak/0310/08/nasional/61124.htm, dalam Rika Saraswati, Hukum Perlindungan Anak di Indonesia, Citra Aditya Bakti, Bandung, hlm. 2015, 131 
Pemasyarakatan berarti memberikan pendidikan buruk bagi anak. Pengalihan proses hukum berupa diversi yang merupakan wujud restorative justice,wajib mempertimbangkan kepentingan korban, kesejahteraan dan dan tanggungjawab anak, dan penghindaran, stigma negatif, menghindaran pembalasan, harmonisasai dan kepatutan serta ketertiban mumum. Pasal 96, 100 dan 101 tentang ancaman pidana bagi aparat penegak hukum yang tidak mengupayakan diversi telah dibatalkan oleh Mahkamah Konstitusi. Mahkamah Agung telah mengeluarkan aturan prosedural untuk pelaksanaan Diversi.

Realitas pelaksanaan diversi pada tingkat pemeriksaan pengadilan: Secara prosedural, pelaksanaan Diversi telah mengacu pada Peraturan Mahkamah Agung No. 4 Tahun 2014. Dalam praktik di lapangan, terdapat kendala tidak dapat dilakukanya Diversi karena terkendala oleh persyaratan yang kaku sebagaimana tersebut pada pasal 7 ayat (2) huruf a. Undang-Undang No. 12 Tahun 2011.

\section{DAFTAR PUSTAKA}

Budiman Al Hanif dalam H.M. Abdi Koro, Perlindungan Anak di Bawah Umum dalam Perkawinan UsiaMuda dan Perkawinan Siri, Cetakan Kesatu, PT.Alumni, Bandung, 2012.

Marlina, Peradilan Pidana Anak di Indonesia (Pengembangan Konsep Restoratuve Justice), Reflika Aditama, Cetakan Pertama, Bandung, November, 2009.

Maulana Hasan Wadong dalam Nashriana, Perlindungan Hukum Pidana bagi Anak di Indonesia, Cetakan Ke-3, PT. RadjaGrafindo Persada, Jakarta,2014.

Maidan Gultom, Perlindungan Hukum terhadap Anak dan Perempuan, Refika Aditama, Bandung, 2014.

Sri Widoyati Wiratmo Soekito dalam Maidin Gultom, Perlindungan Hukum terhadap Anak dalam Ssistem Pidana Anak di Indonesia Cetakan kedua, Refika Aditama,Bandung, 2010.

Rika Saraswati, Hukum Perlindungan Anak di Indonesia, Citra Aditya Bakti, Bandung, 2015.

Ria Helpina, Problematika Penerapan Diversi Dalam Penegakan Hukum Pidana Anak di

Indonesia, (Tesis), Magister Hukum, Pascasarjana Unswagati, 2017.

Wagiati Soetojo, Hukum Pidana Anak, Refika Aditama Cetakan ketiga, Bandung, 2010. 